Koga, E. S.; Oliveira, A.C.; Oliveira, C.S. Perfil dos visitantes nos Parques Estaduais de São Paulo: estudo do Programa Trilhas de São Paulo. Anais do VIII Congresso Nacional de Ecoturismo e do IV Encontro Interdisciplinar de Ecoturismo em Unidades de Conservação. Revista Brasileira de Ecoturismo, São Paulo, v.4, n.4, 2011, p. 554.

\title{
PERFIL DOS VISITANTES NOS PARQUES ESTADUAIS DE SÃO PAULO: ESTUDO DO PROGRAMA TRILHAS DE SÃO PAULO
}

\section{Érika Sayuri Koga*, Anna Carolina Lobo de Oliveira**, Caroline da Silva Oliveira*}

*Secretaria do Meio Ambiente, **Fundação Florestal / SP,

E-mails: erikask@ambiente.sp.gov.br, annaoliveira@sp.gov.br, carolineso@ambiente.sp.gov.br

Programa Trilhas de São Paulo é uma iniciativa da Fundação Florestal em parceria com o Instituto Florestal e a Secretaria do Meio Ambiente do Estado de São Paulo. Tem como objetivo oferecer a oportunidade ao visitante de vivenciar experiências em diversos cenários das Unidades de Conservação do estado, aliando a vivência com a conservação, tornando os Parques Estaduais mais visitados. O Programa foi lançado em agosto de 2008 junto com o "Passaporte Trilhas de São Paulo - Conhecer para Conservar", que consiste em um caderno com informações das trilhas que o programa contempla. Ao total são 40 trilhas distribuídas em 18 Unidades de Conservação espalhadas pelo estado, totalizando $200 \mathrm{~km}$ de trilhas. O objetivo do estudo atual é caracterizar o perfil dos visitantes dos Parques Estaduais no âmbito do Programa Trilhas de São Paulo, através da análise de Pesquisa de satisfação aplicada aos visitantes na Unidade de Conservação após ter concluído a visita. Trata-se de uma pesquisa de natureza quantitativa com 2.408 questionários aplicados entre outubro de 2008 a dezembro de 2010. As respostas foram tabuladas no programa Excel e gerados gráficos e tabelas. Para o presente estudo, foram compiladas todas as questões referentes ao perfil do visitante. Os resultados obtidos trazem dados sobre origem dos visitantes, faixa etária, sexo, motivo da viagem e tipo de grupo que acompanha. Quanto à origem dos visitantes, cerca de $90 \%$ é proveniente do próprio estado, sendo $51,91 \%$ da capital e $40,49 \%$ do litoral e interior, e os $10 \%$ restantes são provenientes da região sudeste $(1,16 \%)$, das outras regiões $(1,0 \%)$, do exterior $(0,12 \%)$ ou não informou $(5,32 \%)$. Em relação à faixa etária dos respondentes, $16,07 \%$ têm entre 14 e 20 anos, 34,34\% têm entre 21 e 30 anos, $23,50 \%$ têm entre 31 e 40 anos e $22,30 \%$ têm mais de 40 anos. Quanto ao sexo dos visitantes entrevistados a diferença foi mínima, sendo $50,71 \%$ do sexo masculino e $47,72 \%$ do sexo feminino. Os entrevistados também foram questionados quanto aos motivos que levaram a visita à Unidade de Conservação, e para $73,13 \%$ o principal motivo foi o lazer, 9,93\% foram para eventos nos parques, $7,41 \%$ foram para fazer pesquisa, $1,80 \%$ foram a negócios e $1,14 \%$ foram fazer uma trilha do Programa Trilhas de São Paulo. E, por fim, quando visitam os parques, normalmente vão com grupos de amigos (38,46\%), em casal (19,56\%), com excursões $(17,19 \%)$, com a família com crianças $(10,34 \%)$, com a família sem crianças $(7,14 \%)$, ou sozinho $(5,19 \%)$. Verificaram-se com este trabalho as principais características dos visitantes às Unidades de Conservação, ficando evidente que há uma demanda específica que visita as áreas naturais. A pesquisa deve ser aplicada e analisada continuamente como base para definições de diretrizes e políticas públicas de ecoturismo no estado, bem como aprimorar serviços de apoio e de divulgação das áreas naturais protegidas. O Programa Trilhas de São Paulo consolida-se como importante ação de fomento à visitação nas Unidades de Conservação, demonstrando demanda considerável de turistas que buscam experiências e atividades de ecoturismo em áreas naturais.

Palavras-chave: Parques Estaduais, Trilhas de São Paulo, Perfil do Visitante 